\title{
MACROECONOMIC TRENDS AMONG VISEGRÁD COUNTRIES, EU BALKANS, AND THE U.S., 1991-2021
}

\section{Gillman, M.}

Max Gillman / University of Missouri-St. Louis, Department of Economics, 1 University

Blvd., St. Louis, MO 63121-4400, United States of America. Email: gillmanm@umsl.edu.

\begin{abstract}
The paper provides an introduction to the special issue. It shows a sense in which Visegrád and Balkan EU countries are correlated in macroeconomic performance and integrated with the global business cycles. Using inflation rate levels as a starting point to characterize when these countries began their transitions, it shows that after 1996 both real GDP growth and real interest rates move together to a significant degree both with each other and with the US. This provides a background from which to view the paths since the collapse of the Soviet Union that these transition economies have taken. In addition, comparison is made to US money and banking policy, to provide an outline of how this may impact progress in the transition region. A subsequent summary of the other articles in the issue shows an inter-relation in their themes about how Central, Eastern, and Southeast Europe have progressed since 1991, and how these paths may be affected by Western economic policy. Implications for Central European audience: The paper shows that transition regions can be impacted by international financial integration, including to possible detriment when capital markets are regulated by policy that pushes real interest rates below their natural levels. Negative real interest rate policy since the 2008-2009 financial crisis and again during the Covid crisis may hasten the rise of autocratic democracy and limit social, political, and economic freedom.
\end{abstract}

Keywords: transition countries; business cycles; real GDP growth rates; inflation rates; real bond interest rates

JEL Classification: P26, P33, P44, P51, E31, E32, E44

\section{Introduction}

The advent of crises has seen large government debt issuance and negative real interest rates dominating since 2008 . This has been an international phenomenon among financially integrated nations. However, in the case of countries dramatically affected by the dissolution of the Soviet Union in December 1991, it is worth starting the investigation by ascertaining the point after which the Visegrád countries, Slovenia and Croatia have 


\section{EDITORIAL}

transitioned to a region converging to global economic trends. Once transitioning towards integration in the global economy, it is shown how they are affected by the same global issues.

Inflation began to settle down in the Visegrád countries, Slovenia and in Croatia after 1996. This paper uses this demarcation to describe key macroeconomic facts along the transition since then. After showing the high, destabilizing, inflation after 1991 and up towards 1996, the paper settles on a study of macro data from 1997 to 2020.

First, the paper shows how the Consumer Price Index based inflation rate has converged to similar levels across these countries starting around 2004. Second, it shows how real output growth, as measured by real Gross Domestic Product (GDP), has moved together since 1997. This is true both among Central and Eastern Europe (CEE) such as the Visegrád countries and in European Union Balkan nations of Croatia and Slovenia, all of which have joined the European Union in 2004 except for Croatia which joined in 2013.

In addition, the cycle in output growth among these nations is shown to move also with a significant correlation with US cycles in GDP growth. This sets the broad outline of how these countries are integrated into the international business cycle of financially connected countries.

Third, by gathering the data on the short-term government bond rates, the real interest rate is derived as a residual using the Fisher (1896) equation of interest rates by which the real rate equals the nominal (market) rate minus the inflation rate. ${ }^{1}$ The paper shows that there is a strong correlation amongst the transition countries and with the US in the real interest rate paths since 1996, including the negative real interest rates that have dominated US data since 2001. The paper discusses how the US negative real interest rate policy can act as a tax on investment and lead to lower growth in the long term. It is proposed that the Great Recession of 2008 and now the Covid crisis propels this negative interest rate policy and that this can imperil both economic growth and democratic political progress across the financially integrated economies. Soros (1990) argues this is even more dangerous for the fringe countries out at the end of the spokes that lead to the hub, to use his analogy. The infringement on democratic institutions is recognized in the other papers of this special issue.

Fourth the paper will briefly outline specifics raised in the other papers in this issue and suggest how their findings are consistent with the thesis that Soros (1990) has put forth. It also argues that these trends are consistent as well with the thesis that the manifestation of negative real interest rates is a propelling factor in weakening democratic institutions that organize business activity. In these ways, this paper provides a broad umbrella under which to view the group of contributions.

International real business cycle theory as in Backus et al. (1992) shows evidence that productivity shocks lead to output and consumption co-movement across economies that are able to transfer savings into investment in the countries undergoing the productivity shock. This means that the countries have an ability to transfer capital amongst each other

1 See Dimand and Gomez Betancourt (2012) for a modern review of the Fisher (1896) equation of interest rates. 
as in financially integrated economies. This theory also allows for the productivity shocks to be correlated amongst countries so that real business cycles can occur in a seemingly correlated fashion. For example, Csaba. et al. (2009) show how the European Union (EU) and the US can borrow and lend capital, and invest within each other, sufficiently enough that their loan premiums are positively correlated across the business cycle in a way that the international real business cycle theory can explain. In contrast, for China relative to each the EU and the US, the loan premiums move in opposite directions as China apparently is less or insufficiently integrated in a financial sense with the EU and US.

While business cycles are dated in the US by the National Bureau of Economic Research, which uses real GDP growth as only one indicator, it is widely accepted that real GDP growth is the main way to characterize the business cycle and to see if countries are moving together as part of a regional or international business cycle movement. The transition countries in Europe began evolving once the Soviet Union was dissolved in December 1991. One key macroeconomic indicator useful for demarcating when the evolution towards international integration began in earnest is the inflation rate.

Section 1 shows how inflation began in the Visegrád countries after the Soviet Union dissolved. Section 2 posits how inflation stabilized from 1997-2021 in the Visegrád and Balkan EU countries, allowing for a period of international integration. Section 3 outlines the real economic growth rates of these countries, with a sense of real national output trending together over 1997-2021, during both Great Recession and Covid crises, while also comoving with US real output. Section 4 derives real bond interest rates across the countries to examine how they move together with the US and EU during the same period, including the negative real interest rate period after 2008. The next Section 5 discusses interest rate policy in the US, while showing how real US and Euro bond rates correlate with the US investment rate in terms of the ratio of bank loans to deposits. Section 6 relates the macroeconomic conditions presented in the paper to the themes of the contributions of the special issue.

\section{What Starting Point for International Integration?}

During the early years after 1991, most CEE and Balkan nations experienced hyperinflation or high inflation as their tax revenue from voluntary citizen payments was minimal and a resort to printing money and taxation through inflation was used. The high inflation caused low and instable GDP growth. As private banking systems were re-enacted and central banks began inflation rate targeting, the taming of the high inflation by around 1996 has given rise to the period after which the Visegrád countries and Croatia began converging towards Western Europe in various facets of macroeconomic activity.

For example, in comparison to other countries in Eastern Europe, Yugoslavia had extreme hyperinflation in 1992-1994. Romania had 300\% inflation and Bulgaria over $1000 \%$ inflation in 1997. Russia's hyperinflation peaked in September 1993 above a 1000\% annual rate, falling to $16 \%$ by the first half of 1997 . For the Visegrád, Poland's inflation rate was above $1000 \%$ in 1990 , but fell to $20 \%$ by the end of 1996 . The Czech Republic experienced bouts 
of inflation above $20 \%$ from 1992-1993. Hungary's inflation rate was close to $40 \%$ mid1991. The Slovak Republic had inflation above $25 \%$ in January $1992 .{ }^{2}$

Figure 1 shows the Consumer Price Index (CPI) inflation rates for the Visegrád Four from 1991 to 1996. These rates were well above those in the EU and the US. However, it is apparent that inflation trended downwards in all four nations during this time. Reaching levels between $5 \%$ and $20 \%$ by 1996 , the inflation rates thereafter continued to converge downwards towards EU and US levels.

Poland had an inflation rate above $60 \%$ in 1991 , dropping to $20 \%$ by 1996 . Hungary had inflation between $20 \%$ and $30 \%$ during the 1991-1996 period. The Czech and Slovak Republics had generally lower inflation and trended down towards $10 \%$ and below.

Figure 1 | Inflation Rates Trended Downwards from 1991-1996 (\%)

\section{Inflation Rate in Visegrad Countries 1991-1996}

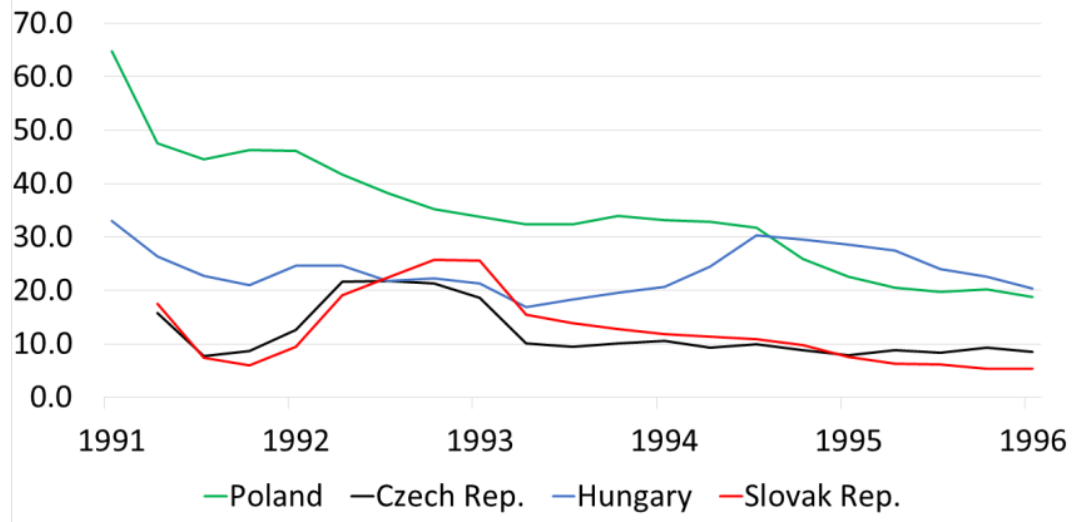

Source: Federal Reserve Bank of St. Louis FRED; https://fred.stlouisfed.org

\section{Stabilization of Inflation after 1996}

The central banks of many countries internationally began adopting inflation rate targeting in the 1990s and continue to do so today. While little acknowledged today, the United States passed a law in 1978 that targeted by law the inflation rate at $3 \%$ by 1983 and zero percent from 1988 onwards; see Gillman (2020). This is called the Full Employment and Balanced Growth Act of 1978 (the Humphrey-Hawkins Act), a law that amends in full the Employment Act of 1946, which stipulates conditions under which the Federal Reserve System operates. Many consider that Paul Volcker achieved a low US inflation rate after the high inflation of the 1970s as a result of his individual accomplishments as Chair of the Federal Reserve System. A different perspective is that Volcker simply carried out the de jure statute and did accomplish an annual US inflation rate of $3 \%$ in 1983, while not achieving the zero target before his tenure ended in 1987. This is in contrast to the

${ }^{2}$ All data in the paper, except income data, is sourced from the Federal Reserve Bank of St. Louis database known as FRED (Federal Reserve Economic Data). 


\section{EDITORIAL}

conventional wisdom that the US Federal Reserve began de facto inflation rate targeting at $2 \%$ in $2012 .^{3}$

The inflation rate targeting regime has intellectual foundations in Lucas and Stokey (1983) who show that it is optimal to keep the inflation tax stable over time just as should fiscal tax rates be kept stable. Added to the literature that showed that the inflation tax was a "bad" tax, in that the optimal rate of inflation typically was found to be its lowest level rather than one commensurate with high taxes on income or sales, as reviewed in Gillman and Yerokhin (2005), inflation rate targeting at low levels became part of US law in 1978 and in international central bank policy targeting "price stability". Price stability itself is a historic goal found for example in Fisher (1913), with a gold standard having been in place in the US since 1873. Recent work still discusses inflation rate targeting versus price level targeting, such as in Burdekin et al. (2012). Taken together, the policy of targeting inflation at a low rate became widespread across financially integrated economies and sprouted in CEE and the Balkans, described in Schaechter et al. (2000). The Czech Republic instituted a law of price stability and exchange rate stability in 1993, adopting inflation rate targeting alone in 1998; 4 the National Bank of Poland adopted an inflation rate targeting policy in 1998 (Horská, 2002); the Slovak Republic began "implicit" inflation rate targeting in 1999 (Krušec, 2011); Hungary implemented an inflation rate targeting law in 2001 (Gillman \& Nakov, 2004).

Figure 2 shows the inflation rates for 1997-2021 for the Visegrád, Slovenia, and the US. There is considerable convergence downwards in the level of the inflation rate, along with co-movement among countries after around 2013. These EU countries show a close correlation with the US inflation rate (dotted line).

\footnotetext{
3 "Although inflation targeting as a formalized monetary policy strategy for achieving price stability is in essence a product of the early 1990s, it has been spreading quite rapidly. The pioneer countries were advanced market economies such as New Zealand, Canada, the United Kingdom, Sweden, Finland, Australia and Spain. However, these have been followed by economies from less developed parts of the world. During the expansion of inflation targeting, it has been significant that the countries applying this regime which were not part of the club. of low-inflation countries have registered a substantial shift to low inflation levels during the 1990s (Czech National Bank, 2000, p. 11)." https://www.imf.org/external/pubs/ft/itarg/2000/eng/chapter7.pdf

4 "The aim of monetary policy and the central bank's objective are laid down in the provisions of Article 98 of the Constitution of the Czech Republic and of Article 2 of Act No. 6/1993 Coll., on the Czech National Bank. These charge the Bank with ensuring the stability of the Czech currency. Monetary stability has an internal dimension (price stability) and an external dimension (exchange rate stability). Achieving and maintaining monetary stability is the central bank's ongoing contribution to the creation of a pro-growth environment (Czech National Bank, 2000);" https://www.imf.org/external/pubs/ft/itarg/2000/eng/chapter7.pdf
} 
Figure 2 | Inflation as Macro Indicator of International Integration (\%)

CPI Inflation Rates, 1997-2021

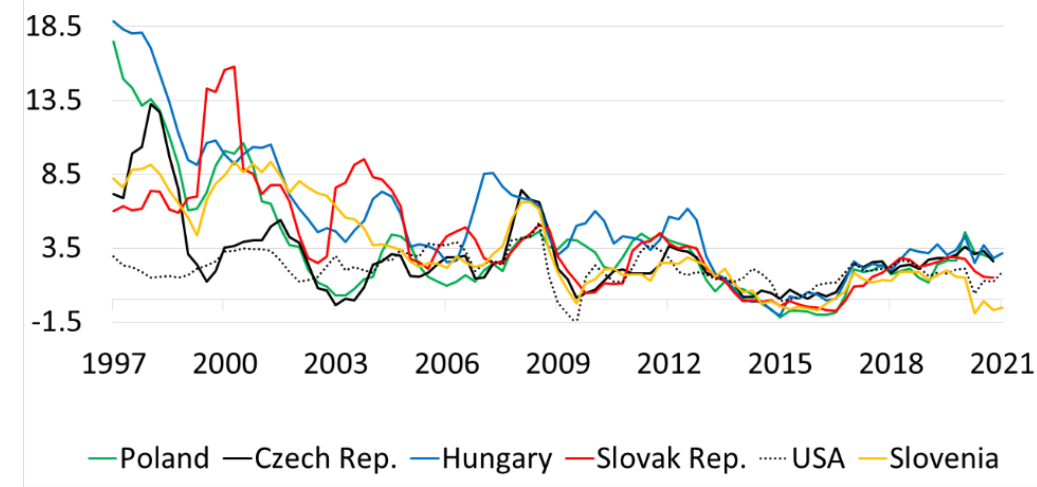

Source: Federal Reserve Bank of St. Louis FRED; https://fred.stlouisfed.org

\section{Output Growth Rate}

The real Gross Domestic Product (GDP) is an inflation adjusted measure of national output. Figure 3 shows the growth rate in real GDP for the Visegrád, EU Balkans, and the US. Since 1996 these growth rates have converged with a strong positive correlation among the countries for 1996-2020. The 2008-2009 Great Recession was only less severe in Poland, while other countries moved closely together. Similar co-movement is also true in the 2020 Covid pandemic recession, with recovery from the trough having begun. The US (dotted line) real GDP pattern can be found to be very similar to these transition countries, implying the way in which they have already become part of the international business cycle comovements.

Figure 3 | Economic Business Cycles in Real Output Correlations Real GDP Growth Rate 1996-2020

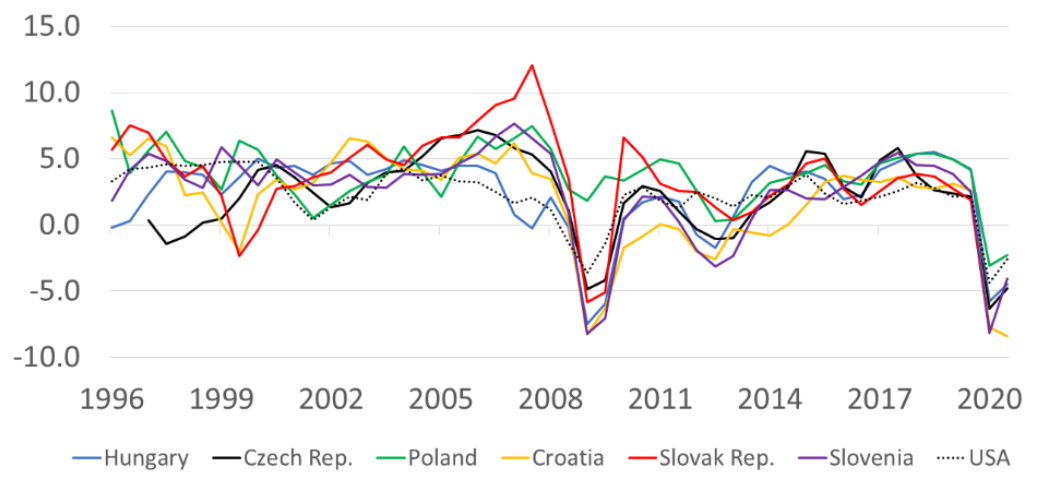

Source: Federal Reserve Bank of St. Louis FRED; https://fred.stlouisfed.org 
Table 1 presents the correlations of the real GDP growth rate for 1997 to 2020 using data sourced from FRED on a semi-annual basis. The US has a correlation averaging 0.76 across the six countries, with the lowest value for Poland at 0.67 and the highest for Hungary at 0.80 . This shows very strong co-movement that signals how the transition countries are a full part of the global economy.

It does emerge that Poland is the least correlated with the rest of the countries. The Czech and Slovak Republics and Hungary are more closely correlated with each other than with Croatia and Slovenia. However, Croatia and Slovenia are less correlated with each other while highly correlated with the US. The strong correlation with the US stands out in a perhaps surprising way from the perspective that the transition countries are still integrating. The latter is true, of course, but integration in terms of co-movement in real GDP is one of the strongest indicators of closely interconnected economies and so belies a lack of integration.

The Great Recession and Covid recessions mark deeply decreased growth across the transition region. This has given rise to very unconventional monetary policy aimed at rescuing the economies. One aspect of this related to both the inflation rate and the real GDP growth rate is the real short-term government bond interest rate policy.

Table 1 | Correlation of Real GDP Growth Rates Across Visegrád, EU Balkans, and US

$\begin{array}{lllllll}\text { 1997Q2- } & \text { Hungary } & \begin{array}{l}\text { Czech } \\ \text { Rep. }\end{array} & \text { Poland } & \text { Croatia } & \begin{array}{l}\text { Slovak } \\ \text { Rep. }\end{array} & \text { Slovenia USA }\end{array}$

\begin{tabular}{|c|c|c|c|c|c|c|c|}
\hline Hungary & 1 & & & & & & \\
\hline Czech Rep. & 0.69 & 1 & & & & & \\
\hline Poland & 0.43 & 0.54 & 1 & & & & \\
\hline Croatia & 0.77 & 0.70 & 0.52 & 1 & & & \\
\hline Slovak Rep. & 0.52 & 0.73 & 0.56 & 0.78 & 1 & & \\
\hline Slovenia & 0.75 & 0.52 & 0.57 & 0.59 & 0.51 & 1 & \\
\hline USA & 0.80 & 0.77 & 0.67 & 0.85 & 0.77 & 0.70 & 1 \\
\hline
\end{tabular}

Source: Federal Reserve Bank of St. Louis FRED; https://fred.stlouisfed.org

\section{Real Short-Term Bond Interest Rates}

The short-term real government bond interest rates can be imputed using the Fisher equation of interest rates by which the nominal, or market, government bond rate $(R)$ is equal to the inflation rate $(\pi)$ plus the real rate of interest $(r)$. By this formula, which we find holds in dynamic general equilibrium monetary models (sometimes called DSGE models), we can use data sourced from FRED. Figure 4 graphs these real short-term bond interest rates for the Visegrád countries, Slovenia, and the US (Croatia is unavailable on FRED). Here the market rate of interest is taken to be the 3-month government bill rate; the inflation rate is the percentage change in the CPI index; and the real bond rate is the residual of subtracting the latter from the former. Put in Fisher equation form: $r=R-\pi$. 


\section{EDITORIAL}

Figure 4 tells several stories about the development of the Visegrád and Balkan EU countries since 1991. First, after 1991, real interest rates were dramatically negative in Poland and the Czech Republic. In the US during the Vietnam War era of the 1970s, some strongly negative real short-term government bond rates were also experienced. During wartime or sudden upheaval, when governments rely on printing money for tax revenue, the inflation rate can accelerate faster than markets anticipate and lead to negative real bond rates. This is especially true for when bond markets are not well developed as perhaps was true in Poland and the Czech Republic just after 1991.

Figure 4 | Real 3-month Government Bond Interest Rates: Market Bond Rate - CPI Inflation Rate (\%)

\section{Real Short Term Govt. Bond Interest Rates}

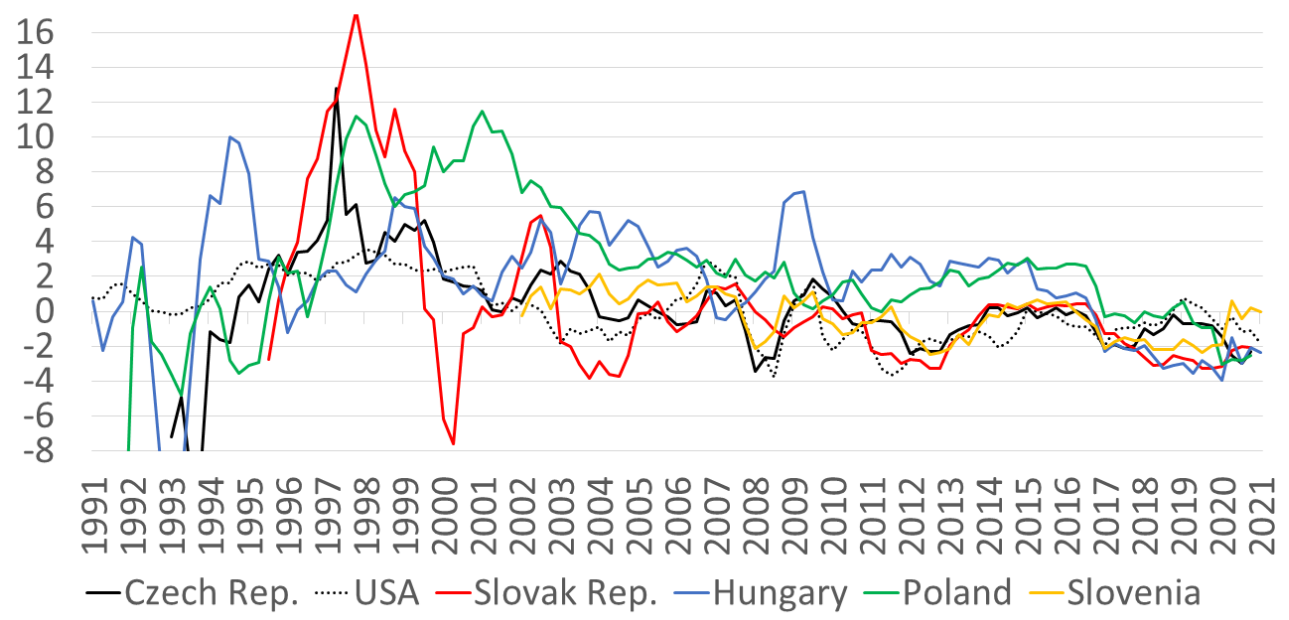

Source: Federal Reserve Bank of St. Louis FRED; https://fred.stlouisfed.org

After 1996, highly negative short-term real government bond interest rates were not experienced, except for one during the year 2000 in the Slovak Republic. Because highly negative real interest rates are unsustainable and a mark of a lack of integration in world capital markets, this reinforces the proposition based on inflation data that these countries began their transition towards integration in global markets near to 1996.

Very high positive real short-term government bond interest rates also indicate serious problems typically lacking in globally integrated economies. The Czech and Slovak Republics and Poland had such high real rates from 1996-2000, and Poland continued to experience high real rates up until EU accession in 2004.

The last period starting in 2004 shows that Hungary and Poland continued to experience real bond rates above those of the other countries all the way up to around 2016. After that there is fairly consistent somewhat negative real rates for all countries including the US. This last period therefore has two notes of interest. First, convergence of real bond rates 


\section{EDITORIAL}

did accelerate after the 2004 EU expansion. Second, despite this, Hungary and Poland continued to experience above average real rates while at the same time being the countries now characterized as the most autocratic democracies. Would it be that these high real bond interest rates foreshadow a lack of integration that can lead to autocratic regimes? This is possible in that such high real bond rates require greater government finance and indicate "too high" real rates than warranted in perhaps more developed economies. These post-2004 high real rates could indicate risk premia built into markets that signal the risky business climate in Hungary and Poland relative to the Czech and Slovak Republics, Slovenia, and the US. Such risk premia can decrease investment overall while favoring risky investment projects in the private economy. Consider the argument about risk premia in terms of the present discounted value (PDV) of the income stream of labor. Let $w$ be the real wage rate per period (adjusted for inflation), and $r$ the real interest rate. Then $w / r$ is the present discounted value of an infinite stream of wages from one period (an hour or a year). If $w$ were equal across the Visegrád and Balkan EU countries, and only $r$ was different, then for a higher risk premium that raises $r$, the PDV of the income stream would be lower as in the case of Hungary and Poland. This would mean a lower value of human capital as the capital value of labor time would be in effect less. A lesser human capital value can lead to discord and an easier rise of autocratic regimes.

Table 2 presents the correlations and averages of the real bond interest rates seen in Figure 4 for the Visegrád countries and the US, for 1997Q2-2020Q2. It shows a strong correlation between the Czech and Slovak Republics, and between Czech and the US, of 0.70 or more. Poland has significant positive correlation with the other countries in the range of 0.41 to 0.60 . Hungary shows the least correlation with other countries, ranging from a 0.06 correlation with the US to a 0.41 correlation, its highest, with Poland.

The real interest rate correlation results present evidence that supports how currently the most autocratic democracy of the Visegrád, Hungary, has been the least correlated with US real bond rates. The highest correlation for Hungary is with Poland, probably the second most autocratic democracy today of the Visegrád. The Czech and Slovak Republics in contrast have higher correlations with the US and each other and appear to be the least autocratic democracies of the Visegrád.

The real interest rate correlations arguably show important markers that are consistent with how Hungary and Poland may have strayed from more liberal democratic constitutions, much as Russia began to do in a somewhat more extreme fashion after 2000 . The value of human capital that results from using discount factors such as the real government bond rate gives a ranking that can be compared to the per-capita real income levels across the Visegrád.

Table 2 indicates that the average real bond rates are $3.13 \%$ for Poland, $1.76 \%$ for Hungary, $0.57 \%$ for the Czech Republic, and $0.51 \%$ for the Slovak Republic. For 2019, Eurostat gives an annual wage rate of 16.1 thousand Euros for Poland, 13.2 for Hungary, 15.2 for the Czech Republic, and 11.2 for the Slovak Republic. Dividing these wages by the average real rates of Table 2, this gives from highest to lowest: $15.2 / 0.57=26.7$; for the Czech Republic, 11.2/0.51 = 22.0 for the Slovak Republic, 13.2/1.76 = 7.5 for Hungary and 
16.1/3.13 $=5.1$ for Poland. ${ }^{5}$ This calculation of the PDV of wages coincides with the Czech and Slovak Republics being with higher average human capital and less autocratic democracies, versus Hungary and Poland with much lower average human capital and much more autocratic democracies.

Table 2 | Correlations of Real 3-month Government Bond Interest Rates

\begin{tabular}{lllllll}
$\begin{array}{l}\text { 1995Q3- } \\
\text { 2020Q4 }\end{array}$ & Czech Rep. & $\begin{array}{l}\text { Slovak } \\
\text { Rep. }\end{array}$ & Hungary & Poland & USA & $\begin{array}{l}\text { Aver. Real } \\
\text { Rate }\end{array}$ \\
\hline Czech Rep. & 1.00 & & & & 0.57 \\
Slovak Rep. & 0.71 & 1.00 & & & 0.51 \\
Hungary & 0.33 & 0.21 & 1.00 & & 1.76 \\
Poland & 0.60 & 0.49 & 0.41 & 1.00 & & 3.13 \\
USA & 0.70 & 0.57 & 0.06 & 0.53 & 1.00 & 0.003
\end{tabular}

Source: Federal Reserve Bank of St. Louis FRED; https://fred.stlouisfed.org; Eurostat

However, it is important to qualify these simple PDV data comparisons by noting how negative real interest rates on short-term debt negates the ability to use them in discounting value, which is why averages are used above. Prolonged negative real interest rate periods are arguably a result of monetary policy actions that effectively fix market rates at levels below the inflation rate, which can induce a whole set of implicit taxes, just as fixing a price in any market during the Soviet Union caused multiple economic distortions.

\section{Negative Real Interest Rate Policy}

Figure 5 shows for 1976-2020 how the ratio of the US commercial loans to total deposits (solid black), in percentage change terms (and normalized by dividing by 6 ), moves roughly together with the real US 3-month government bond rate (dotted) and with the Euro-area 3month government bond rate (since 1998, light grey solid), as sourced from FRED. The correlation between the percentage change in the ratio of loans to deposits and the US real bond interest rate is 0.33 for the 1976Q1-2020Q4 period, a significant positive comovement. If instead we start at 1984Q1, at a time when US inflation rate targeting has taken hold, and go to 2020Q4, the correlation rises to 0.43 .

The rate of change in the loan to total deposit ratio shows a dimension of how the private bank sector investment changes over time. Banks intermediate consumer savings deposits into firm investment loans, so it is an indicator of how private investment changes over the business cycle. Its positive correlation with the real interest rate could be viewed as a net movement upwards along the schedule indicating the rate of supply of loans by banks as the rate of demand for investment shifts out. With financial intermediation built into real business cycle models, as in Csabafi et al. (2009), this is the type of dynamics that can be seen in a full general equilibrium model.

${ }^{5}$ Annual net earnings of a full-time single worker without children earning an average wage (online data code: EARN_NT_NETFT). 


\section{EDITORIAL}

Figure 5 shows the strong co-movement of the Euro area real government bond 3-month interest with the other two US data series as well. This evidence supports how along the economic business cycle, investment of deposits by banks into loans rises as the real bond interest rate rises, and falls as the bond rate falls. This is consistent with real business cycle theory whereby productivity rises and falls over the business cycle so as to cause the capital rental real interest rate (the marginal product of capital net of depreciation) to likewise rise and fall, or move pro-cyclically. The real bond interest rate and investment rate in terms of loans to deposits change in a similar pro-cyclic fashion.

Figure 5 | Normalized Percentage Change (\%) in Loan to Deposit Ratio (solid black), Real US Bond Rate (dotted), Real Euro Area Bond rate (grey solid).

\section{Loans to Deposits Ratio, Real Bond Int. Rates}

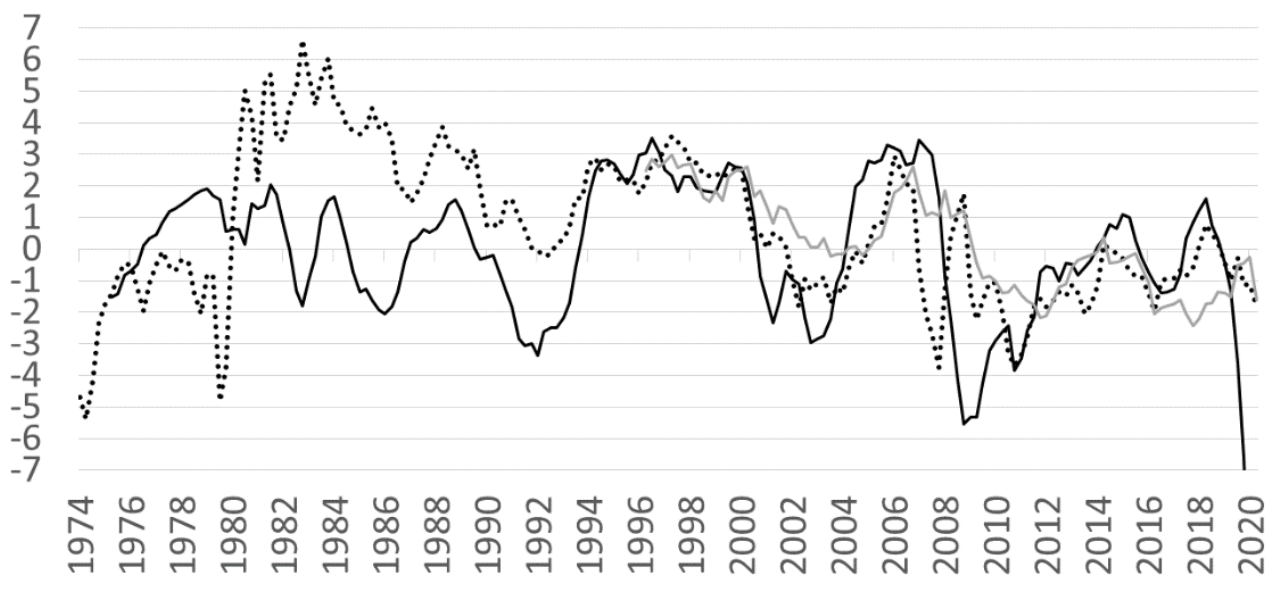

—US: Loans/Deposits....US Real Bond Int. Rt. - Euro Real Bond Int. Rt.

Source: Federal Reserve Bank of St. Louis FRED; https://fred.stlouisfed.org

Figure 5 shows several other features related to facts mentioned in the context above. Negative real bond rates and very high real bond rates, as in the US 1970s and early 1980 s, lead to more subdued increases in the loan to deposit ratio during upswings in the economy. Similarly, during the post-2008 period, the percentage increase in the ratio of loans to deposits was much lower than the levels seen during the high economic growth periods of the US mid-1980s and 1990s. The US 1960s, 1980s, and 1990s all had healthy levels of real bond interest rates in the $2 \%-3 \%$ average range. In contrast, the post-2008 period saw sustained negative real bond interest rates, both in the US and in Europe, with below trend real GDP growth. This makes the post-2008 period subject to being called a "lost decade", just as Japan's 1990s were called, and as occurred in the US from 19291938. In the US Great Depression post-1929 decade, not only was it a low real GDP growth era, but the level of real GDP only recovered to its 1929 level after a decade.

The lost decade of the Great Depression era led to extremism arising in Europe with fascism in two forms taking hold, in terms of the Nazi regime in Germany and the strengthening of the Communist regime in the Soviet Union. This led directly to World War 


\section{EDITORIAL}

II, many argue, and was even arguably foreseen by Keynes (1919) who strenuously prescribed that all war reparations from Axis countries be cancelled. Indeed, the German partial payment of war reparations led subsequently to uncontrolled hyperinflation and the rise of the Nazi regime. This danger of hyperinflation or high inflation leading to extreme political autocracy remains today. This lesson was learned after WWII when the US instituted the Marshall plan of making loans to Germany and Japan in exchange for democratic constitutions being enacted. This is a lesson the EU can take into the post pandemic period when the money supply growth rate has dramatically increased internationally.

Dramatic increases in the rate of growth of the money supply is the source of the story as to how the US ended up paying interest on reserves and effectively repressing world financial capital markets through regulation of the market rate of interest on government bonds. This story is a convoluted one and its outcome has been that markets have had difficulty in untangling the ramifications of the new set of monetary and banking policies (the latter being called macroprudential policy) that the US started and caused an international spread of its policy.

First, is it too much US-centric to argue that the US money and banking policy has been spread internationally? The integration of economies financially in global capital markets can easily lead to such a spread by a dominant democracy and center of world finance.

Consider the 1970s breakdown of the Bretton Woods Agreement of a gold standard regime backed by the US dollar, whereby only central banks could redeem US dollars for gold at $\$ 32$ an ounce through the US Federal Reserve Bank. Starting in the 1950s, the US became involved in Vietnam, picking up after the French and then the British interventions in "Indochina". As the US involvement accelerated throughout the 1960s, peaking with the Tet offensive in 1968, the US debt rose and the US Fed bought a steady share of the debt, thereby "printing money" to finance the Vietnam War. This led to rising US inflation. The fixed exchange rates of the Bretton Woods system required other signatory nations in Western Europe to print their own currencies at a rate necessary to buy up the excess US dollars that were entering their nations. To keep these Bretton Woods exchange rates in place, the US effectively exported its inflation to the other nations. Finally, France had enough and started cashing in the US dollars for gold through the Fed gold window and President Nixon "closed the gold window" on August 15, 1971, thus officially starting the end of the Bretton Woods system. It took two more years for fully floating exchange rates to be established.

The danger of the US negative real interest rate policy is that it too has spread internationally to economies integrated in the global economy. Why? Simply, if for example the EU does not want the Euro to appreciate against the US dollar when the US is instituting negative real interest rates through Federal Reserve policy, then the EU must also run negative real rates in the Euro area or else capital will flow into the higher yielding Euro area and cause the Euro to appreciate against the US dollar. The problem with such appreciation is that it would dampen exports of the Euro area. The same holds for why Japan, the UK, and even Switzerland (after first letting the Swiss franc double in value 


\section{EDITORIAL}

relative to the US dollar) needed negative real interest rate policies as well. To avoid appreciation against the US dollar and dampen exports.

Of course, Switzerland was the interesting case, in that exports were not important to its financial industry of shadow banking. However when countries like Hungary had their banks begin a whole new mortgage loan market, for which they tended to make loans dominated in the stable Swiss franc, the Hungarian households with mortgages were unable to make monthly mortgage payments (using forints) when the mortgage doubled in amount because the Swiss franc doubled in value. So even Switzerland was pressured to print money. The curious events in Switzerland were that there was little Swiss government debt to "monetize" through the Swiss National Bank (SNB) buying the debt. Therefore, the SNB began buying a large swath of its private economy and still holds these assets today as a result of the US negative real interest rate policy that has spread internationally. This is an effective nationalization of the Swiss economy, which goes against the notion of healthy deregulated democracies and against the de-nationalization of industry for example in the UK under Prime Minister Thatcher.

The US negative real interest policy arguably came about through stealth actions of the Federal Reserve that may have had an unintended outcome relative to their motivation. To see this, consider the following anatomy of this policy. In 2006 the US passed Public Law 109-351, "The Financial Services Regulatory Relief Act of 2006". It stipulates in Section 201 that "Balances maintained at a Federal Reserve bank by or on behalf of a depository institution may receive earnings to be paid by the Federal Reserve bank at least once each calendar quarter, at a rate or rates not to exceed the general level of short-term interest rates." Despite the sponsoring Senator Crapo's intent that this was only meant to avoid taxing banks with the reserve requirement of holding non-interest bearing reserves at the Fed, this law eventually evolved into payment of interest on all reserves, including excess reserves. At the time the ratio of reserves to total deposited loans had been trending downwards for nearly 30 years, from $5 \%$ to close to $1 \%$. This is because of several reasons. Banks insured by the Federal Deposit Insurance Corporation (FDIC) needed to only hold $10 \%$ reserves on deposits up to a certain low level, and $3 \%$ on all deposits higher than that level. Meanwhile, vast amounts of deposits had been going into investment banks as "money market funds," or "mutual funds", that were not required to hold any reserves since they were not part of the FDIC. This yielded an effective reserve to deposit ratio by in the US of close to $1 \%$ by the time of the 2006 law. Therefore the intent was simply to keep the FDIC banks from being disadvantaged relative to the vast money market and mutual fund banks.

For example, consider that the demand deposits of FDIC banks stopped growing around 1981 when US inflation peaked, and FDIC banks were restricted by the 1933 US Banking Act as to the maximum interest they could pay (Regulation $Q$ ). As a result of paying interest below the market rate in the 1980s, their deposit growth became near zero right up until the 2008 investment bank crisis, while money market funds grew dramatically; essentially all new deposits went into money market funds rather than FDIC banks.

After setting interest rates in the US Federal Funds market at levels below the inflation rate for three years in 2002-2004, by continually ramping up the growth rate of the money 


\section{EDITORIAL}

supply after 2001, the Fed under Governor Bernanke then decided to seek more normal, positive, real bond rates by raising the Federal Funds rate (FFR) from 1\% in May 2004 steadily up to $5.3 \%$ in August 2006, an increase in the level of the interest rate by $4.3 \%$ over two years. The result was widespread default on variable rate mortgages taken out during the near three preceding years of negative real interest rates, since households mortgages taken out at a $1 \%$ rate in 2003 would see their interest payments double at a $2 \%$ rate, triple at $3 \%$ and find themselves quickly in default. The worldwide bundling up of these "safe" mortgage loans into assets called "mortgage-backed securities", and the selling of these securitized loans across the global financial system, led to defaults on banks internationally when the Fed suddenly raised the FFR by $4.3 \%$ points. Yes, a healthy positive real interest rate was reached through this Fed regulation and sudden deregulation of capital markets, but with the consequence of global financial collapse of economies financially integrated with the US.

After the 2008 crisis, the Fed enacted the same policy again of massive money supply growth and pushing the FFR down towards zero. But then the Fed came up with a brandnew twist on the policy that effectively sterilized the money supply growth. This policy kept new money from entering circulation and causing inflation, while simultaneously leading to unending negative real interest rates internationally that caused low growth for the post2008 decade. In particular, the Fed changed the 2006 law allowing interest on "reserves" to start immediately in 2008, instead of the legally stipulated date of 2011 , and then applied this to all reserves, rather than the intended target of only required reserves. The language of the 2006 law was loose on this, although Senator Crapo's statements on intent make clear the law was targeting only required reserves. The lawmakers may have used the word "reserves" instead of "required reserves" since in all previous US history excess reserves had always been statistically close to zero. So, in 2008 the Fed began buying US Treasury debt from banks (keeping a near constant fraction of the US Treasury debt held by the Fed, but at a time when US Treasury debt was rising at historically unprecedented rates since WWII), thereby "printing money" in the classical sense at a very high rate.

However, then the Fed came up with the idea of paying interest on the reserves, held at the Fed by the private banks, that were created when the Fed bought the US Treasury debt from the banks. This meant that the Fed paid the private banks for the PDV of the interest stream on the Treasury debt, and then paid the bank interest on the debt that the banks no longer held, a double interest payment. This was done by the simple feat of paying interest on excess reserves, an unintended consequence of the vague wording of the 2006 Act. The Fed took advantage of this 2006 Act so that they could claim to be meeting their objective of inflation rate targeting. They did meet this objective. The unforeseen consequence was that the interest rate on excess reserves (IOER) became the market rate of short-term US government debt. Since this rate was set below the inflation rate for 10 years until 2018, the Fed regulated capital market interest rates at levels below the inflation rate in order to sterilize the massive money supply increase and lay claim to achieving their inflation rate target despite monetizing so much of the US Treasury debt. The consequent negative real interest rates set a global platform for the level of real bond rates that was instituted across the UK, EU, Japan, Switzerland and further afield. Some countries other than the US, where there were insufficient bonds to buy, began instituting negative real nominal or 


\section{EDITORIAL}

market interest rates. While perhaps seen first in countries like Switzerland, the ECB began such policy in 2014.

The IOER policy coincided with the first time in US history, in the at era after the breakdown of the Bretton Woods gold standard, banks began building up massive amounts of excess reserves that rose from zero to $\$ 2.7$ trillion by September 2014 . Why would banks hold and continue to build up excess reserves when the IOER was set at only $0.25 \%$ from January 2009 until December 2015? One can speculate based on several economicpolitical scenarios. Federal Reserve minutes apparently indicate that only ten banks were holding this massive level of reserves and these same "systematically important banks", and that the US Congress was debating increasing reserve requirements of non-FDIC banks so that these banks would want to keep high reserves to avoid further regulation. Indeed the Dodd-Frank Act of 2010 did raise reserve requirements on the non-FDIC banks. Second, the interest from IOER is a pure subsidy elicited from the Fed since it is a double interest payment on Treasury debt, one that may not last under further Congressional oversight. The Congressional Reconciliation Budget process requires all expenditures from the US Treasury to any sector to be approved in budget legislation.

Through the IOER policy, the Fed is simply skirting the Congressional budget process by diverting straight to banks what would otherwise be seigniorage payments made back to the US Treasury for which Congress would then decide on its allocation. Therefore, banks may have preferred to yield this "free" subsidy in a low risk holding of excess reserves during a time when the economy may have still been financially fragile. This subsidy effectively paid banks not to invest deposits as loans, but rather to keep the money held at the Fed, thus sterilizing part of the Fed's dramatic increase in the money supply growth rate. Since loans create new private bank money in the form of demand deposits, the IOER policy and excess reserves could well be said to create the moral hazard of inducing less investment while conducting inefficient ex-post bank insurance (rather than having an exante system in place as in the risk-based premium fees of the FDIC system). This is why it is interesting to see the loan to deposit ratio and how it is relatively low during negative real interest periods. Indeed, as soon as the Fed began raising the IOER especially after President Trump was criticizing the Fed for its regulation of capital markets, the IOER rate rose above the inflation rate briefly from November 2018 to October 2019, the excess reserves fell steadily, the inflation rate was rising as more loans were made, and the capital markets became effectively much less regulated in the sense of the real interest rate moving towards its fundamental value.

To put it graphically, Figure 6 shows an example capital market with an interest rate $r$. By the IOER policy of setting the nominal market interest rate at for example $0.25 \%$ for seven years, one could argue that the real interest rate $r$ was forced down by, say, a $1.25 \%$ inflation rate to a $1.0 \%$. The natural market equilibrium here is $2.45 \%$ in the graph (dashed line) where the private quantity supplied of capital equals the private quantity demanded for capital. At negative one percent, instead there is an excess demand for capital by the private sector. The red line is the private capital supply plus the supply of Treasury debt that the Fed buys and that shifts out the total supply curve. The intersection of the red supply curve with the $1.0 \%$ interest rate ceiling indicates the total capital demanded including the 


\section{EDITORIAL}

excess reserves that are held at the Fed and effectively enforces the negative interest rate ceiling. The triangle of deadweight loss of both foregone producer and consumer surplus is outlined by where the $1.0 \%$ real interest rate intersects the private supply of capital as given by the upward sloping black line. By raising the IOER so that the real interest rate $r$ rises to $2.45 \%$; the market would be back to an undistorted equilibrium.

\section{Figure 6 | Effective Ceiling on Real Interest Rate $\mathbf{r}$ in Capital Market}

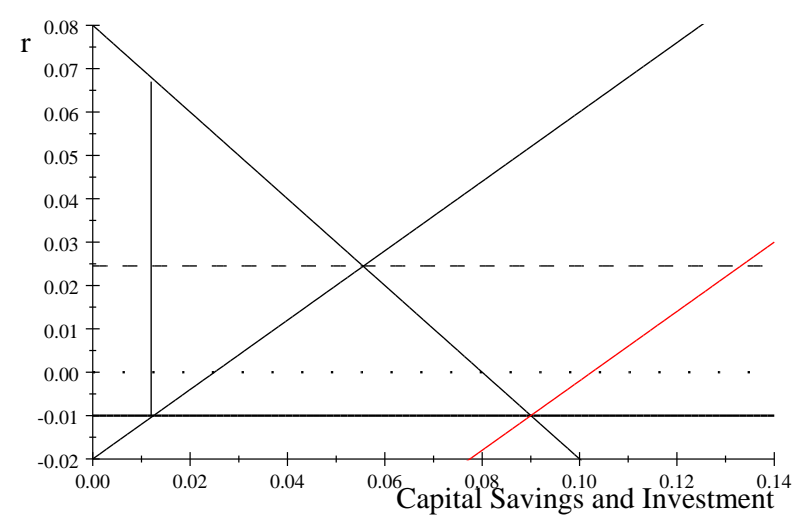

Source: author

Consider how an artificially low real rate gives rise to increased private demand for capital but decreased private supply of capital. Forcing a negative real rate leads to less investment because private borrows are discouraged from offering savings so that private investment cannot go up as it would like given the negative rates. The Fed has effectively created a ceiling in the market for capital on real interest rates that causes an unending excess demand for private capital as long as the negative real interest rate policy continues. The problem with Fed policy trying to avoid inflation while inducing the holding of excess reserves, massively increasing the rate of growth of the money supply, setting the IOER, and effectively regulating capital markets is that it effectively taxes capital markets worldwide, leads to lower growth, and subsidizes the rise of extremist, or autocratic, democratic regimes that take advantage of the economic chaos that can erupt in countries on the fringes of the global financial system such as the CEE and Balkan countries.

With the Covid crisis, with the 2001 terrorist attacks, with the 2008-2009 financial crisis, low real interest rates may well be warranted. Ten years of such policy leads to extremism of the fringes of democracy as well as in the centers of democracy including the US. This is a danger that needs to be stated given the 2020 start of the Covid pandemic and the use of the same prolonged US negative real interest rate policy once again. Indeed, in 2020 the US Fed eliminated all reserve requirements and simply pays IOER on all reserves. This could be seen as ironic in that the 2006 Act arose in the first place because of perceived indirect disadvantages to FDIC banks in having to hold required reserves. So now the "tail" of the 2006 Act "wags the dog" of international capital markets through the IOER regulation 
by the US Fed, rather than letting capital markets freely determine real interest rates internationally. Could such policy, if prolonged, lead to even more extremism than the Covid pandemic itself may have caused?

\section{Relation to Contributions in the Special Issue}

The four other papers of this special issue all deal with the rise of autocratic democracies and the dangers therein for Central and Eastern Europe and the Balkans. This paper has provided a macroeconomic background for why these other papers may come to the conclusions that they do, all of which are consistent with the themes of this paper. The other papers are contribution by Lajos Bokros, Ivan Mikloš, Marek Dabrowski, and Velimir Šonje, with special foci respectively on Hungary, the Slovak Republic, Poland, and Croatia.

Consider a brief overview of each paper's contribution in turn. Lajos Bokros served as Minister of Finance of Hungary in 1995-1996, subsequently served as a member of the European Parliament, and is a longtime Professor in the Economics and Public Policy departments of Central European University (CEU). CEU is a US charted institution that itself became a victim of extreme autocratic democracy when Hungary outlawed its UScharted programs and forced CEU to leave Hungary and reestablish itself in Vienna in 2019, a remarkable turn of events. Bokros has therefore had a first-hand view of the trends in Hungary and Central and Eastern Europe through governmental, political and academic endeavors.

Bokros' contribution characterizes the stages of transition that Hungary has gone through. He emphasizes how productivity and investment have stymied in recent years, a trend that can be strengthened by the negative real interest rate policy that the US has been following. Bokros argues that continuing convergence towards Western standards or what Bokros (2013) terms "Accidental Occidental" in his fascinating 2014 book, are threatened by the lack of rule of law. His perspective is that restoring the rule of law in such democracies is their last hope for avoiding the lack of freedom and prosperity, as in the Russian autocratic model, and instead grasping the Western Europe and US more democratic model.

The other authors of this special issue have been equally involved. Ivan Mikloš likewise has served in government and academics. Mikloš was Minister of Finance in Slovakia from 2002-2006 and in the Slovak Republic in 2010-2012, and has been a Lecturer at the University of Trnava. ${ }^{6}$ Mikloš' contribution characterizes the transition process since 1991 into three categories of gradualist transformation, radical transformation, and spontaneous transformation. He starts with János Kornai's work on characterizing the Soviet Union model and carries his analysis across a broad swath of CEE including "latecomers" such as Ukraine and Georgia. He also finds importance for the rule of law for example by finding that nations with a stronger history of democratic institutions tended to fair better after the Soviet Union dissolution.

\footnotetext{
${ }^{6}$ Mikloš also served as Deputy Prime Minister (Economy) from 1998-2000 in Slovakia and from 2002-2006 in the Slovak Republic, and as Minister of Privatization of the Czech and Slovak Federative Republic from 1991-1992.
} 
Marek Dabrowski similarly has a rich career in government, research institutes and academics, with dozens of published articles in economics and policy. ${ }^{7}$ Along with his long record of government service in Poland, ${ }^{8}$ Dabrowski cofounded the Center for Social and Economic Research (CASE) in Poland, has current affiliations with other institutes including Bruegel, the E.T. Gaidar Institute for Economic Policy, CASE Ukraine, and is a Professor at the Higher School of Economics University, Moscow. Dabrowski's contribution focuses on the economic versus the non-economic causes of the recent reversal of democratic reforms made in the years after 1991. He emphasizes the danger from autocratic regimes becoming entrenched and limiting freedoms of social and economic exchange, with a particular threat seen through the technological and political ability to agglomerate media control in government.

Velimir Šonje is a well-known analyst across Croatia and South East Europe (SEE). With a specialization on banking and monetary policy, he has served in the Croatian National Bank, major private banks, founded the Ekonomski Lab and was researcher the Institute of Economics Zagreb, with many academic publications. ${ }^{9}$ Šonje describes the integration of the whole of SEE. He finds a great deal of convergence up until the Great Recession of 2008-2009, after which divergence became more common even for Slovenia. With a focus on Croatia, Šonje conceptualizes a sling effect by which integration can take place more soundly when the historical institutional environment is more deeply founded in the legal frameworks that allow freer markets and social interaction.

Taken together these four contributions provide a broad yet deep insight into the path of Central, Eastern, and Southeastern Europe after "the fall of the wall" in Berlin and the collapse of the Soviet Union. The themes put forth intertwine with each other and allow great insight into what has transpired to date. They set up the platform for thinking about how reforms might go forward that can lead to strengthened liberty and rights and economic progress in this crucial region that stands on the frontline of democracy.

\section{Conclusion}

The special issue of the Central European Business Review includes four contributions from authors across the Visegrad and Balkan EU countries. Their articles provide specialized insight to the economic, social, and political turmoil that these countries and the rest of the transition region has suffered while striving to remake themselves in a new form with greater liberty in all spheres. These authors have incredible first-hand experience in helping shape the paths that these countries have taken. Their expert roles in forming liberty have led them to decry the recent trends backwards. My paper here has provided a

\footnotetext{
${ }^{7}$ Dabrowski's research can be found at the Federal Reserve Bank of St. Louis REPEC website; https://ideas.repec.org/f/pda247.html

${ }^{8}$ Dabrowski served as: "Secretary of State (First Deputy Minister) in the Ministry of Finance (1989-1990), Chairman of the Council of Ownership Transformation under Prime Minister (1990-1995), Member of Parliament (and

Parliamentary Budget and Financial Committee .1991-1993), Member of the Advisory Board to the Governor of the

National Bank of Poland (1993-1997), Member of the Monetary Policy Council of the National Bank of Poland (1998-

2004), coauthor of inflation targeting strategy adopted by the NBP in 1998-2000. (Higher School of Economics

University, Moscow; online published CV; https://www.hse.ru/en/org/persons/112929885)."

${ }^{9}$ Šonje's publications can be found at ResearchGate: https://www.researchgate.net/pro.le/Velimir-Sonje
} 
macroeconomic overview of these trends based on inflation, real output growth, and real interest rates, to provide parameters that frame this debate about the future directions that the region will take. I have also put in perspective how US monetary and banking policy may affect the ability of the region to progress well.

\section{Acknowledgement}

The authors gratefully acknowledge support of the University of Missouri - St. Louis Hayek endowment fund, and appreciates discussion at Central European University, the Institute of Economics Centre for Economic and Regional Studies of the Hungarian Academy of Sciences (CERS), Budapest, and the Center for Economic Research and Graduate Education- Economics Institute (CERGE-EI), Prague. I also thank Lajos Bokros, Kreso Zigic, Marek Dabrowski, Szilard Benk and Michal Kejak for suggestions and/or past discussion.

\section{References}

Backus, D. K., Kehoe, Patrick, J., \& Kydland, F. E. (1992). International Real Business Cycles. Journal of Political Economy, 100(4), 745-775.

Bokros, L. (2013). Accidental occidental: Economics and culture of transition in Mitteleuropa, the Baltic and the Balkan Area. Central European Press.

Burdekin, R. C., Mitchener, K. J., \& Weidenmier, M. D. (2012). Irving Fisher and Price-Level Targeting in Austria: Was Silver the Answer?. Journal of Money, Credit and Banking, 44(4), 733-750.

Csabafi, T. Z., Gillman, M., \& Naraidoo, R. (2019). International business cycle and financial intermediation. Journal of Money, Credit and Banking, 51(8), 2293-2303.

Czech National Bank. (2000). Inflation Targeting in the Czech Republic - Chapter VII in Inflation Targeting in Transition Economies: The Case of the Czech Republic. Edited by Warren Coats, CNB and IMF, March.

Dimand, R. W., \& Gomez Betancourt, R. (2012). Retrospectives: Irving Fisher's Appreciation and Interest (1896) and the Fisher Relation. Journal of Economic Perspectives, 26(4), 185-96.

Federal Reserve Bank of St. Louis FRED; https://fred.stlouisfed.org

Fisher, I. (1896). Appreciation and Interest. Publications of the American Economic Association, First Series, 11(4), 1.110 [331.442], and as Appreciation and Interest, New York: Macmillan, 1896.

Fisher, I. (1913). A compensated dollar. The Quarterly Journal of Economics, 27(2), 213-235.

Gillman M. (2020). The welfare cost of inflation with banking time. The B.E. Journal of Macroeconomics, 20(1), 1-20.

Gillman, M., \& Nakov, A. (2004). Granger causality of the inflation-growth mirror in accession countries. Economics of Transition, 12(4), 653-681.

Gillman, M. K., \& Yerokhin, O. (2005). Ramsey-Friedman optimality with banking time. Topics in Macroeconomics, 5(1), 1-24.

Horská, H. (2002). Inflation targeting in Poland, a comparison with the Czech Republic. Prague Economic Papers, 11(3), 237-254; https://doi.org/10.18267/j.pep.196. 
Krušec, D. (2011). Is inflation targeting effective? Monetary transmission in Poland, the Czech Republic, Slovakia, and Hungary. Eastern European Economics, 49(1), 52-71.

Lucas Jr, R. E., \& Stokey, N. L. (1983). Optimal fiscal and monetary policy in an economy without capital. Journal of monetary Economics, 12(1), 55-93.

Schaechter, A., Stone, M. R., \& Zelmer, M. (2000). Adopting inflation targeting: Practical issues for emerging market countries. International Monetary Fund.

Soros, G. (1990). Opening the Soviet System. Weidenfeld \& Nicolson.

The editorial passed the review process by other authors of the special issue. | Received: April 30, 2021; Revised: May 5, 2021; Accepted: May 27, 2021; Published: June 1, 2021. 